\title{
Rare occurrence of the leatherback sea turtle, Dermochelys coriacea, in Izmir Bay, Aegean Sea, Turkey
}

\section{İzmir Körfezi'nde (Ege Denizi, Türkiye) nadir rastlanan bir deri sırtlı deniz kaplumbağası, Dermochelys coriacea, vakası}

\author{
Ertan Taşkavak $^{1 *}$ • Salim Can Akçınar ${ }^{1}$ Çağlayan Inanlı \\ ${ }^{1}$ Ege Üniversitesi, Faculty of Fisheries, 35100, Bornova, Izmir-Turkey \\ ${ }^{2}$ Karşıyaka Municipality, Directorate of Veterinary Affairs, Karşıyaka, Izmir-Turkey \\ 'Corresponding author: ertan.taskavak@ege.edu.tr
}

\section{How to cite this paper:}

Taşkavak,E., Akçınar,S.C., Inanlı,C., 2015. Rare occurrence of the leatherback sea turtle, Dermochelys coriacea, in Izmir Bay, Aegean Sea, Turkey. Ege J Fish Aqua Sci 32(1): 51-52. doi: 10.12714/egejfas.2015.32.1.08

Özet: Deri sırtı deniz kaplumbağası, Dermochelys coriacea, pelajik ve dünya genelinde dağılım gösteren ve IUCN Kırmızı Liste'de Hassas olarak listelenmiş bir türdür. Daha çok Pasifik ve Atlantik Okyanus'larında bulunmasına rağmen, Akdeniz'e zaman zaman giriş yapar. Akdeniz'deki gözlemlerin çoğu Batı Akdeniz'dendir. Türkiye'nin Ege Denizi kıyılarında ilk kez on yıldan fazla süre önce görülen türe, bu kayıtta 28 Eylül 2011 yılında İzmir Körfezi'nde ölü olarak karaya vurmuş halde rastlanmışıtır. Bulunan ergin dişi kaplumbağanın $148 \mathrm{~cm}$ eğik karapas boyuna ve $198 \mathrm{~kg}$ ağırlığa sahiptir. Karapasında, büyük olasiıkla gemi pervanesi sebebiyle oluşan, dikine derin iki yarı̆ga rastlanmıştır.

Anahtar kelimeler: Dermochelys coriacea, Deri sırtı deniz kaplumbağası, karaya vurma, İzmir Körfezi, Ege Denizi, Türkiye

Abstract: Leatherback sea turtle, Dermochelys coriacea, is a pelagic and circumglobal species and listed Vulnerable in IUCN Red List. Although the species mainly inhabits the Atlantic and Pacific Oceans and occasionally enters the Mediterranean Sea. Most of the sightings have been made in the western part of the Mediterranean. More than a decade after the species' first record in the Aegean coasts of Turkey, the recent specimen were found stranded dead on the coast of Izmir Bay on October 28, 2011. The mature turtle was a female with $148 \mathrm{~cm}$ of curved carapace length and $198 \mathrm{~kg}$ of weight. Two deep transversal cuts which seem to be caused by a boat propeller were observed on carapace.

Keywords: Dermochelys coriacea, Leatherback sea turtle, stranding, Izmir Bay, Aegean Sea, Turkey

\section{INTRODUCTION}

Populations of leatherback sea turtles, Dermochelys coriacea (Vandelli, 1761), are assumed to be decreasing globally (Spotila et al. 1996; Pritchard 1982), and they are listed as Vulnerable in IUCN Red List (Wallace et al., 2013). Although the species mainly inhabits the Atlantic and Pacific Oceans, they occasionally enters the Mediterranean Sea, and most of the sightings have been made from the western part of the Mediterranean (Casale et al. 2003). Few records available from the Eastern Mediterranean countries including Greece (Margaritoulis 1986), Syria (Rees et al. 2004), Israel (Levy et al. 2005), Cyprus and Egypt (Casale et al. 2003).

Leatherbacks have been observed sporadically from Turkish coasts. The first documented record seems to be an individual caught by fishermen and brought to the harbor of Antalya in 1983 (Baran and Kasparek, 1989). Subsequently, Oruç et al. (1996) mentioned that fishermen from Karataş and Yumurtalık, Bay of Iskenderun, occasionally observe leatherbacks, and that in 1995 a single dead $D$. coriacea was recovered from their nets and brought ashore at Karataş. Additionally, an officer of the local (Karataş) authority of the Ministry of Agriculture also encountered and photographed a carcass on the beach in the Strait of Hurma (Hurma Boğazı). Another dead specimen was found stranded on the shore in the vicinity of the Anamur-Bozyazı Highway (Taşkavak and Farkas, 1998). Most recent record of the species from Turkey was obtained from Eastern Mediterranean in 2006 (Sönmez et al. 2008). The individual was found dead in the Iskenderun Bay, and its tag revealed that it marked at Matura beach, Trinidad, in 2005 (Sönmez et al. 2008).

In addition to the several records from the southern coasts, only two observation were made from the Aegean coasts of Turkey (Taşkavak and Farkas, 1998). One of them was a male with $126 \mathrm{~cm}$ straight carapace length, caught in a gillnet in Edremit Bay, northern Aegean, and the other specimen was caught live in a trammel net by a local fisherman in Izmir Bay, and released back to sea in a healthy condition. The size and 
sex of the ladder were undetermined (Taşkavak and Farkas, 1998; Taşkavak et al. 1998)

More than a decade after the species' first record from the Aegean coasts of Turkey (Taşkavak and Farkas, 1998; Taşkavak et al. 1998), the recent specimen were found stranded on the coast of Izmir Bay on October 28, 2011. The mature turtle was a female with $148 \mathrm{~cm}$ of curved carapace length and $198 \mathrm{~kg}$ of weight. The length from tip to tail end was
$183 \mathrm{~cm}$. The distance between the front limbs was $199 \mathrm{~cm}$. No tag was found. Two deep transversal cuts which seem to be caused by a boat propeller were observed on carapace (Figure 1). Small wound was measured as $40 \mathrm{~cm}$, while larger one located almost on middle of the carapace (we thought it was fatal) was about $50 \mathrm{~cm}$. No record of nesting by leatherbacks in Mediterranean is confirmed yet, so individuals observed in eastern Mediterranean are assumed to originate from Atlantic Ocean colonies.

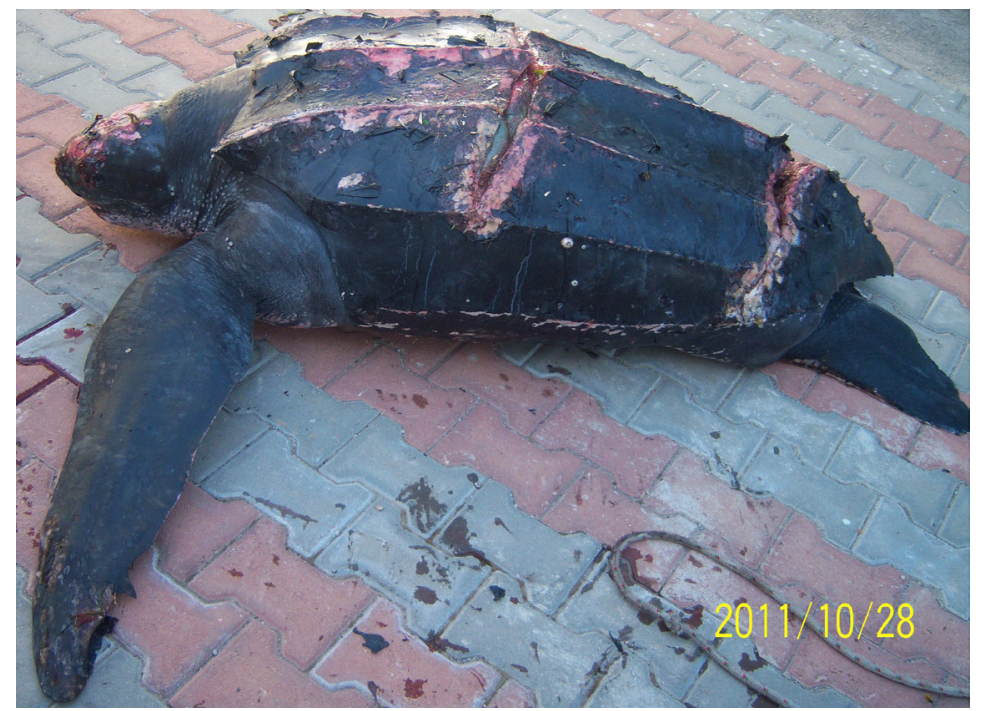

Figure 1. The stranded leatherback turtle, Dermochelys coriacea (Vandelli, 1761), on the coast of Izmir Bay, Turkey, on October $28,2011$.

\section{REFERENCES}

Baran, I., Kasparek, M., 1989. Marine turtles-Turkey status survey 1988 and recommendations for conservation and management. WWF publication 123pp.

Casale P., Nicolosi, P., Freggi, D., Turchetto, M., Argano, R., 2003. Leatherback turtles (Dermochelys coriacea) in Italy and in the Mediterranean Basin. Herpetological Journal 13:135-139.

Levy, Y., King, R., Aizenberg, I., 2005. Holding a live leatherback turtle in Israel: lessons learned. Marine Turtle Newsletter 107:7-8

Margaritoulis, D. M., 1986. Captures and strandings of the leatherback sea turtle, Dermochelys coriacea, in Greece (1982-1984). Journal of Herpetology 20(3):471-474. doi: 10.2307/1564521

Oruç, A., Demirayak, F., Sat, G., 1996. Fishery in the Eastern Mediterranean and its Impact on Marine turtles: The Conclusive Report. Istanbul: DHKDWWF

Pritchard, P. 1982. Nesting of leatherback turtle Dermochelys coriacea in Pacific Mexico, with a new estimate of the world population status. Copeia 4: $741-747$. doi: $10.2307 / 1444081$
Rees, A.F., Saad, A., Jony, M., 2004. First Record of a Leatherback Turtle in Syria. Marine Turtle Newsletter(106):13

Sönmez, B Sammy, D Yalcin-Ozdilek S. Gönenler, O.A Acikbas, U Ergün, Y., Kaska, Y., 2008. A Stranded Leatherback Sea Turtle in the Northeastern Mediterranean, Hatay, Turkey. Marine Turtle Newsletter (119): 12-13.

Spotila, J.R., Dunham, A.E., Leslie, A.J., Steyermark, A.C. Plotkin, PT, Paladino, F.V., 1996. Worldwide population declines of Dermochelys coriacea: Are leatherback turtles going extinct? Chelonian Conservation and Biology 2(2):209-222

Taşkavak, E., Boulon, R.H. Atatür, M.K., 1998. An Unusual Stranding of a Leatherback Turtle in Turkey. Marine Turtle Newsletter (80):13

Taşkavak, E. Farkas, B., 1998. On the occurrence of the Leatherback Turtle Dermochelys coriacea, in Turkey (Testudines: Dermochelyidae). Zoology in the Middle East 16:71-75. doi: 10.1080/09397140.1998.10637756

Wallace, B.P., Tiwari, M. \& Girondot, M. 2013. Dermochelys coriacea. The IUCN Red List of Threatened Species. Version 2015.2. <www.iucnredlist. org>. Downloaded on 13 July 2015. 